\title{
CRAYFISH OCCURRENCE IN RELATION TO LAND-USE PROPERTIES: IMPLEMENTATION OF A GEOGRAPHIC INFORMATION SYSTEM (GIS).
}

\author{
H.K. SCHULZ (1), P. SMIETANA (2), R. SCHULZ (1)
}

(1) Zoological Institute, Technical University, Fasanenstrasse 3, D-38092 BRAUNSCHWEIG, Germany. E-mail : Holger.Schulz@tu-bs.de

(2) Department of Ecology, University of Szczecin, ul. Waska 13, PL-71-415 SZCZECIN, Poland.

\begin{abstract}
On the basis of inventory data collected since 1994, the recent stocking situation for freshwater crayfish in three 10 by $10 \mathrm{~km}$ study sites in northeastern Germany (Uckermark) and northwestern Poland (Szczecin area, Koszalin area) is described. The native crayfish Astacus astacus (L.) was found in two of the three study sites (Uckermark, Koszalin area) with 1 and 7 stocks, respectively, while the American species Orconectes limosus (Raf.) was found in all three study areas, and in two of them (Uckermark, Szczecin area) was the dominant crayfish species.

By means of spatial analysis on the basis of a geographic information system (GIS), influence of land-use properties and other human impact on crayfish distribution was estimated. $A$. astacus was found only in lakes with a proportion of arable land below $10 \%$ within a $50 \mathrm{~m}$ buffer around the shoreline. Proportion of forest around these lakes was above the average for all lakes. In contrast, $O$. limosus appeared indifferent to all factors related to land use. Average lake size was clearly different for the two species. A. astacus was found in smaller lakes without direct contact to settled areas, whereas $O$. limosus preferentially inhabited larger lakes, indicating the importance of human activities in respect of extinction of native crayfish stocks and propagation of alien crayfish species. GIS proved a suitable tool for the assessment of land-use effects and overall human impact on crayfish distribution on a landscape level.
\end{abstract}

Key-words : Astacus astacus, distribution, extinction, freshwater decapod, GIS, human impact, land use, Orconectes limosus. 


\section{PRÉSENCE DES ÉCREVISSES EN FONCTION DES PROPRIÉTÉS D'UTILISATION DES TERRES : APPLICATION D'UN SYSTĖME D'INFORMATION GÉOGRAPHIQUE.}

\section{RÉSUMÉ}

Sur la base des relevés effectués depuis 1994, la situation récente des stocks d'écrevisses dans trois sites d'étude (de $10 \mathrm{~km}$ sur 10) de l'Allemagne du nord-est (Uckermark) et de la région de Pologne du nord-ouest (région de Szczecin, région de Koszalin) est décrite. L'espèce d'écrevisse autochtone Astacus astacus (L.) a été trouvée dans deux des trois sites (Uckermark, région de Koszalin) avec 1 et 7 stocks, respectivement, tandis que l'espèce américaine Orconectes limosus (Raf.) a été trouvée dans les trois sites d'étude. Elle a été l'espèce d'écrevisse prédominante dans deux de ces sites (Uckermark, région de Szczecin).

L'influence de l'utilisation des terres et d'autres impacts humains sur la distribution des écrevisses ont été estimés en utilisant la technique d'analyse spatiale sur la base d'un système d'information géographique (GIS). A. astacus a été trouvée exclusivement dans les lacs avec une proportion de terre labourable inférieure à $10 \%$ dans une zone de $50 \mathrm{~m}$ autour de la rive. La proportion de forêt autour de ces lacs était supérieure à la moyenne de tous les lacs. Par contre, $O$. limosus a semblé indifférente à tous les facteurs relatifs à l'utilisation des terres. L'aire moyenne des lacs était clairement différente pour les deux espèces. A. astacus a été trouvée dans des petits lacs sans contact direct avec des colonies tandis que $O$. limosus a occupé surtout les lacs plus grands. Ceci indique l'importance des activités humaines dans l'extinction des stocks d'écrevisses indigènes et la propagation des espèces d'écrevisses introduites. Le GIS a prouvé son utilité pour l'évaluation des effets de l'utilisation des terres et de l'influence humaine totale sur la répartition des écrevisses au niveau régional.

Mots-clés : Astacus astacus, distribution, décapode d'eau douce, extinction, GIS, influence humaine, Orconectes limosus, utilisation des terres.

\section{INTRODUCTION}

Four native crayfish species are found in Germany and Poland: Astacus astacus, Astacus leptodactylus, Austropotamobius pallipes and Austropotamobius torrentium. By far the most widely distributed of them is A. astacus (L.) or noble crayfish (DEHUS et al., 1999; STRUZYNSKI and SMIETANA, 1999). According to German (National Wildlife and Conservation Law and National Endangered Species Act) and European conservation guidelines (EU Habitats Directive), A. astacus is a protected species (SCHULZ, 2000). Until the end of the $19^{\text {th }}$ century, this species had been widespread in central Europe and in some regions of great commercial interest (ALBRECHT, 1983). However, outbreaks of crayfish plague, competition from introduced alien crayfish and increasing pollution problems (fertiliser, pesticides) have led to a dramatic loss of populations (SCHULZ and SMIETANA, 2001).

According to SCHULZ (2000) there are at least 719 stocks of $A$. astacus in Germany, documented after 1990, characterised by a patchy distribution. They exhibit high geographical isolation, being mostly restricted to small tributaries and isolated lakes. As a 
consequence these populations are dependent on a single habitat where endangering impacts are not diluted and reserves and potentials for resettlement are lacking (BOHL, 1999).

A cross-border monitoring of 300 lakes in northeastern Germany and northwestern Poland conducted by SCHULZ and SMIETANA (2001) revealed great differences in the stocking situation of the two regions. The study indicates a large number of crayfish-free lakes in the Uckermark (northeastern Germany), whereas in northwestern Poland almost all suitable lakes are occupied by the introduced crayfish species Orconectes limosus (Raf.). The underlying mechanisms have not been examined so far, but the extensive, uncontrolled transfer of $O$. limosus has been discussed as a possible reason for the recent situation in northwestern Poland.

Increasingly, knowledge of the habitat requirements of native crayfish combined with the assessment of potential threats turns out to be an essential basis for the conservation of remaining stocks and successful reintroduction measures (BOHL, 1999). A comprehensive study of the status of $A$. astacus and its habitat situation in Bavaria (Germany) was conducted by BOHL (1989). Similarly, the habitat requirements of the autochthonous crayfish species Austropotamobius pallipes have been analysed in Britain and Spain (SMITH et al., 1996; NAURA and ROBINSON, 1998; GARCIA-ARBERAS and RALLO, 2000). These studies are confined to running waters, the main habitat of native crayfish in hilly areas. But in principle the noble crayfish can inhabit very diverse bodies of water, lotic and lentic, from the lowland plains into the mountains (BLOHM et al., 1994). In lowland areas lakes are even more significant as habitat of the noble crayfish. In Schleswig-Holstein $75 \%$ of stocks have been reported from lakes (DEHUS, 1990). Similar observations have been made in Brandenburg (KNUTH and MIETZ, 1993), Lower Saxony (BLANKE, 1998) and Thuringia (MNLU, 1996).

The above-mentioned investigations primarily took into account the water body and the shoreline. Regarding parameters related to water quality, the noble crayfish is not strictly dependent on clear water; it can also live in water with light to severe contamination (BLANKE, 1998). Nevertheless, a low oxygen content, contamination by toxic substances and a muddy bottom are among the limiting factors for their survival. In this respect the input of liquid manure, pesticides and fertiliser from agricultural land prove to be problematic (DEHUS, 1996; HAGER, 1996). Observations by BOHL (1987) indicate that stocks of noble crayfish are mostly found in brooks which are not or only slightly influenced by agriculture. However, up to now the influence of land use on crayfish distribution has not been studied systematically.

There are of course other kinds of human activity that pose a threat to native crayfish stocks. Particularly the introduction of alien crayfish species or the accidental propagation of the crayfish plague have been discussed as the main factors for the extinction of many stocks (ALDERMANN, 1996; HAGER, 1996; BOHL et al., 2001). Also intensive stocking of predatory fish and overexploitation are suspected to endanger crayfish populations (FEDOTOV et al., 1993; STRUZYNSKI and SMIETANA, 1999). The standard of knowledge on this topic is mainly based on descriptions of individual cases or historical data (see papers in GHERARDI and HOLDICH, 1999). The overall influence of such factors on the distribution of native crayfish on a regional scale has not been measured so far.

The aim of this study is the assessment of the crayfish distribution in northeastern Germany and northwestern Poland with regard to land-use properties and overall human impact. A geographic information system (GIS) provides a suitable tool for the analysis of environmental factors on a landscape level and was therefore implemented in this study. 


\section{MATERIAL AND METHODS}

\section{Inventory}

Three different regions in northeastern Brandenburg and northwestern Poland are compared to analyse the importance of different land-use parameters and human impact on the distribution of crayfish: Uckermark (Brandenburg), Szczecin area (Poland), Koszalin area (Poland) (Figure 1). All three regions are characterised by their abundance of natural lakes formed during the last lce Age but show differences in their human population density and relevance of agriculture (Table II). In each region, a 10 by $10 \mathrm{~km}$ square was defined and named after the next big village or town: Prenzlau (Uckermark), Insko (Szczecin area), Bialy Bor (Koszalin area). All lakes with minimum size of 0.5 ha at least partly overlapping the area of the squares were included in the subsequent examinations.

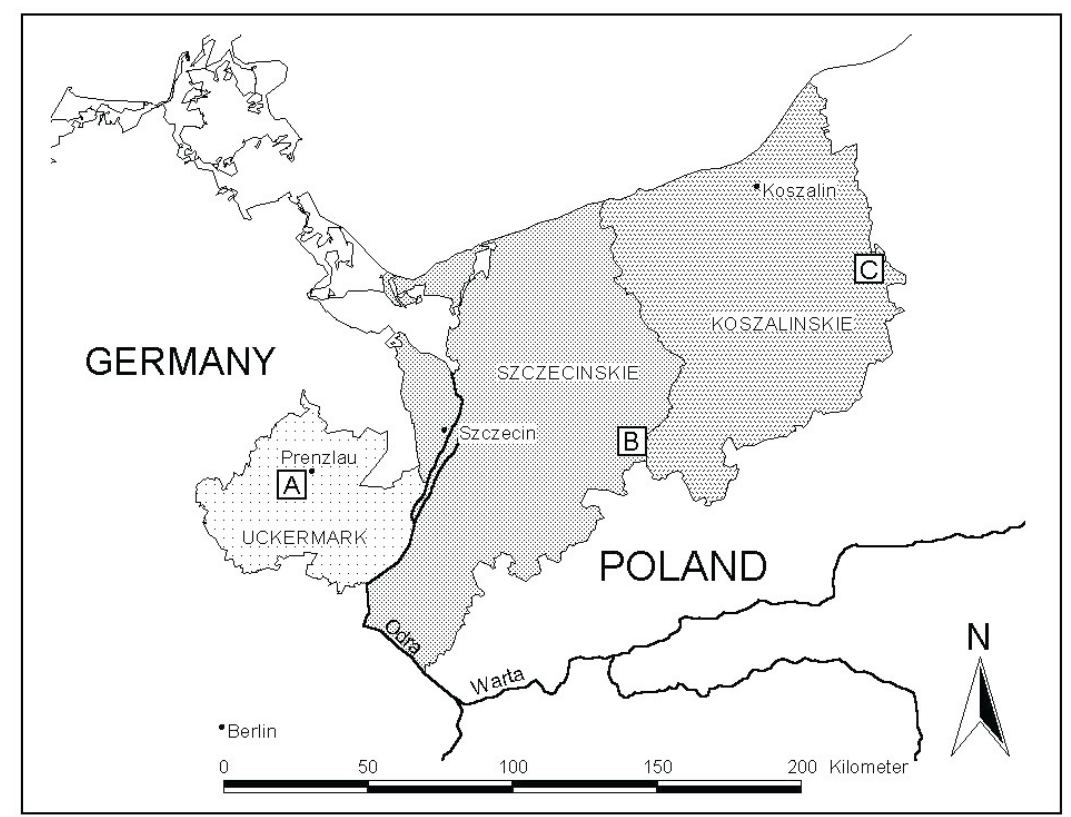

\section{Figure 1}

Map of the study area. The three 10 by $10 \mathrm{~km}$ squares named Prenzlau (A), Insko (B), Bialy Bor (C) belong to the Uckermark (Germany), the Szczecin area (Poland) and the Koszalin area (Poland).

\section{Figure 1}

Carte de la région d'étude. Les trois quadrats de $10 \mathrm{~km}$ sur $\mathbf{1 0}$, nommées Prenzlau (A), Insko (B), Bialy Bor (C), appartiennent à l'Uckermark (Allemagne), à la région de Szczecin (Pologne) et à la région de Koszalin (Pologne).

The distribution of crayfish species was established from field studies conducted between 1994 and 2001. Inspection of the littoral area during the night period was followed by trapping with baited trap-nets or scuba diving according to methods outlined in SCHULZ (2000). 


\section{GIS analysis}

For Germany digital maps of the study area and data on land use were provided by the following organisations: Brandenburgisches Landesvermessungsamt (digital landscape model - DLM25/1), Landesumweltamt Brandenburg (inventory of biotopes based on aerial survey photographs of 1992). For Poland data on land-use was taken from 1:50 000 Ordnance Survey maps, status of 1975-1978.

For a first estimation of the differences between the three regions, the following types of land use were distinguished and their proportion in the square area was measured using the desktop GIS software $\operatorname{ArcView}^{\oplus}\left(\mathrm{ESRI}^{\mathrm{TM}}\right)$ : settlements, arable land, meadows, swamp, forest, watercourses. In a second step the crayfish occurrence was linked with lake size and land use by a buffer analysis. That is, a buffer with a width of $50 \mathrm{~m}$ was drawn around the shoreline of each lake. The portion of total buffer area was calculated for following types of land use: settlements, arable land, meadow, swamp, forest. Additionally, the distance from each lake to the nearest settlement was estimated by measuring the distance between the central points of their polygons. Most of the variables used in the buffer analysis did not follow a normal distribution. For this reason the median was used in Table III for the description of the results. Differences between species were tested for significance with the Mann-Whitney-U-Test.

The species' preference for or avoidance of a certain parameter was calculated as electivity index E (RICKLEFS, 1979):

$$
E=(r-p) /(r+p)
$$

where $r=$ mean value of a certain parameter for lakes inhabited by a particular crayfish species; $p=$ mean value of this parameter for all lakes.

The electivity index was originally used for the description of predator-prey relationships. Its application for habitat modelling was propagated by BLASCHKE (1997). Values for $E<0$ indicate an avoidance of this parameter, values for $E>0$ indicate a preference for this parameter.

\section{RESULTS}

\section{Inventory}

The results of the crayfish stock inventory are summarised in Table I. The three selected squares contained a total of 92 lakes with minimum size of 0.5 ha. During the field studies 55 of them were checked for crayfish occurrence. Two crayfish species were found in the studied area. In two of three regions, Prenzlau and Bialy Bor, the native crayfish Astacus astacus was found with one and seven stocks respectively. The introduced species $O$. limosus occurred in all three regions, and was the dominant crayfish species in Prenzlau and Insko.

\section{GIS analysis}

The land use differed between the three selected squares (Table II). In the order Prenzlau, Insko, Bialy Bor the proportion of the area used for settlements decreased from 3 to $1 \%$, the proportion of arable land decreased from 61 to $25 \%$ and the proportion of forests and swamps increased from 20 to $55 \%$ and 2 to $5 \%$ respectively. The proportion of meadows was about the same in all three regions. A special feature of the Insko region was the large area covered by lakes in spite of their relatively small number. 
Table I

Occurrence of crayfish in $\mathbf{1 0}$ by $\mathbf{1 0} \mathbf{~ k m}$ squares in the three study areas Prenzlau (Uckermark), Insko (Szczecin area), Bialy Bor (Koszalin area). The data refer to monitoring conducted between 1994 and 2001.

\section{Tableau I}

Présence de l'écrevisse dans les quadrats de $10 \mathrm{~km}$ sur 10 des trois sites d'étude

Prenzlau (Uckermark), Insko (région de Szczecin), Bialy Bor (région de Koszalin). Les données se rapportent aux relevés effectués entre 1994 et 2001.

\begin{tabular}{l|cccc}
\hline & Total no. & \multicolumn{3}{c}{ Region } \\
\cline { 3 - 5 } & of sites & Prenzlau & Insko & Bialy Bor \\
\hline Astacus astacus & 8 & 1 & 0 & 7 \\
Orconectes limosus & 23 & 9 & 10 & 4 \\
Without crayfish & 24 & 11 & 6 & 7 \\
Unknown status & 37 & 10 & 0 & 27 \\
\hline
\end{tabular}

Table II

Proportion of different land-use features in 10 by $10 \mathrm{~km}$ squares in the three study areas Prenzlau (Uckermark), Insko (Szczecin area), Bialy Bor (Koszalin area).

\section{Tableau II}

Proportion des différentes propriétés d'utilisation des terres dans les quadrats de $10 \mathrm{~km}$ sur 10 des trois sites d'étude Prenzlau (Uckermark), Insko (région de Szczecin), Bialy Bor (région de Koszalin).

\begin{tabular}{l|ccc}
\hline & \multicolumn{3}{|c}{ Region } \\
\cline { 2 - 4 } & Prenzlau & Insko & Bialy Bor \\
\hline Settled areas [\%] & 3 & 2 & 1 \\
Arable land [\%] & 61 & 40 & 25 \\
Meadows [\%] & 12 & 10 & 10 \\
Swamps [\%] & 2 & 3 & 5 \\
Forests [\%] & 20 & 35 & 55 \\
Surface waters [\%] & 2 & 10 & 4 \\
\hline
\end{tabular}

The Insko region comprised the biggest lakes of the study area, with a median size of 17.7 ha, followed by Bialy Bor with a median of 3.0 ha and Prenzlau with 1.5 ha. The distance from each lake to the next area of settlements was about the same for Prenzlau and Insko, $0.5 \mathrm{~km}$. In Bialy Bor the lakes were more remote from settlements, at a median distance of $1.1 \mathrm{~km}$. Most of the lakes in all three regions have little or no contact to settlements, indicated by a median proportion of settlement area of 0 . Regarding the proportion of arable land, the Prenzlau region and the Insko region also show a similar aspect. As median 29 and $25 \%$ of the buffer areas are covered by arable land. In contrast, the lakes in the Bialy Bor region have mostly no direct contact to arable land. The proportion of forest decreased in the order Prenzlau, Insko, Bialy Bor. 
Species-specific differences of lake size and land-use features are also evident in Table III, e.g. proportion of arable land or proportion of forest. These are further analysed in Figure 2 and Figure 3.

\section{Table III}

Median size and median proportion of different land-use features of the lakes in the study areas Prenzlau (Uckermark), Insko (Szczecin area), Bialy Bor (Koszalin area) itemised by known crayfish stocks. The proportion of different land-use features was estimated by a buffer analysis of the lakes. A.a. = A. astacus; O.I. = O. limosus; no = without crayfish; all = all lakes.

Tableau III

Aire médiane et proportion médiane des différentes propriétés d'utilisation des terres dans les sites d'étude Prenzlau (Uckermark), Insko (région de Szczecin), Bialy Bor (région de Koszalin) spécifié par les stocks des écrevisses connus. La proportion médiane des différentes propriétés d'utilisation des terres a été estimée par une analyse de mémoire tampon des lacs. A.a. = A. astacus; O.I. = O. limosus ; no = lacs sans écrevisses ; all = tous les lacs.

\begin{tabular}{|c|c|c|c|c|c|c|c|c|c|c|c|c|}
\hline & \multicolumn{4}{|c|}{ Prenzlau } & \multicolumn{4}{|c|}{ Insko } & \multicolumn{4}{|c|}{ Bialy Bor } \\
\hline & A.a. & O.I. & no & all & A.a. & O.I. & no & all & A.a. & O.I. & no & all \\
\hline $\mathrm{N}$ & 1 & 9 & 11 & 31 & 0 & 10 & 6 & 16 & 7 & 4 & 7 & 45 \\
\hline Lake size [ha] & 0.7 & 3.6 & 1.3 & 1.5 & - & 41.3 & 3.1 & 17.7 & 7.9 & 29.1 & 5.1 & 3.0 \\
\hline $\begin{array}{l}\text { Distance to nearest } \\
\text { settlement }[\mathrm{km}]\end{array}$ & 0.9 & 0.4 & 0.5 & 0.5 & - & 0.9 & 0.3 & 0.5 & 0.9 & 1.5 & 0.5 & 1.1 \\
\hline Settled areas [\%] & 0 & 0 & 0 & 0 & - & 0 & 0 & 0 & 0 & 0 & 0 & 0 \\
\hline Arable land [\%] & 2 & 29 & 58 & 29 & - & 18 & 50 & 25 & 0 & 13 & 0 & 0 \\
\hline Meadows [\%] & 98 & 23 & 2 & 21 & - & 10 & 15 & 10 & 0 & 0 & 0 & 0 \\
\hline Swamps [\%] & 0 & 1 & 0 & 0 & - & 0 & 0 & 0 & 0 & 0 & 0 & 0 \\
\hline Forests [\%] & 0 & 12 & 0 & 12 & - & 75 & 10 & 33 & 95 & 83 & 70 & 70 \\
\hline
\end{tabular}

Figure 2 illustrates the electivity index of the crayfish species $A$. astacus and $O$. limosus for the investigated parameters. A. astacus inhabited lakes distinct from the average with regard to the parameters lake size, settlement area, arable land and forest. In general this species was found in smaller lakes with no nearby settlements and only a small proportion of arable land but a high proportion of forest. The sole exception to this general pattern is the single stock of $A$. astacus in the Prenzlau region. It was found in a lake with $98 \%$ of the surrounding area covered by meadows (Table III). The occurrence of the introduced species $O$. limosus was unrelated to most of the examined parameters except for lake size. $O$. limosus was most frequently found in lakes larger than the average of all lakes. Habitats of $A$. astacus and $O$. limosus showed significant differences in relation to the proportion of arable land $(\mathrm{U}$-Test, $\mathrm{p}<0.001)$ and the proportion of forest $(\mathrm{U}-\mathrm{Test}$, $\mathrm{p}<0.05)$.

Figure 3 shows the dispersal of lakes along a proportion gradient of arable land differentiated by the crayfish species. A. astacus occurred only in lakes with a proportion of arable land less than $10 \%$. In contrast $O$. limosus was detected in lakes with a proportion of arable land up to $60 \%$. All investigated lakes with more than $60 \%$ of arable land $(n=7)$ were free of crayfish. 


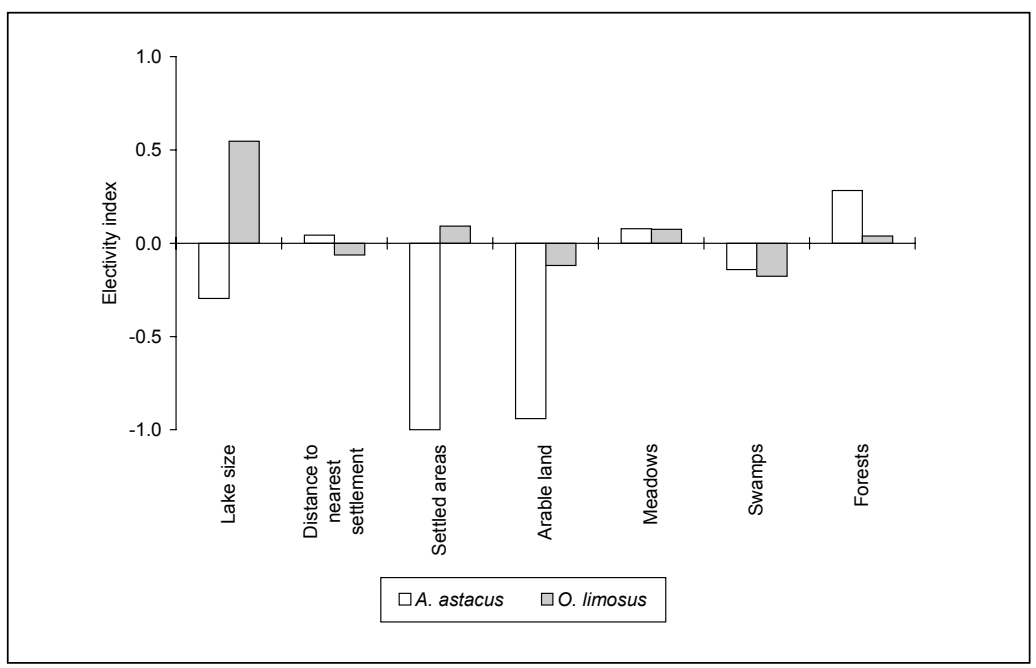

Figure 2

Electivity index of the species $A$. astacus and $O$. limosus calculated according to RICKLEFS (1979) with regard to lake size, distance to next settlement and different land-use features.

Figure 2

Index de préférence des espèces $A$. astacus et 0 . limosus, calculé selon RICKLEFS (1979), en ce qui concerne l'aire de lac, la distance à la prochaine colonie et les différentes propriétés d'utilisation des terres.

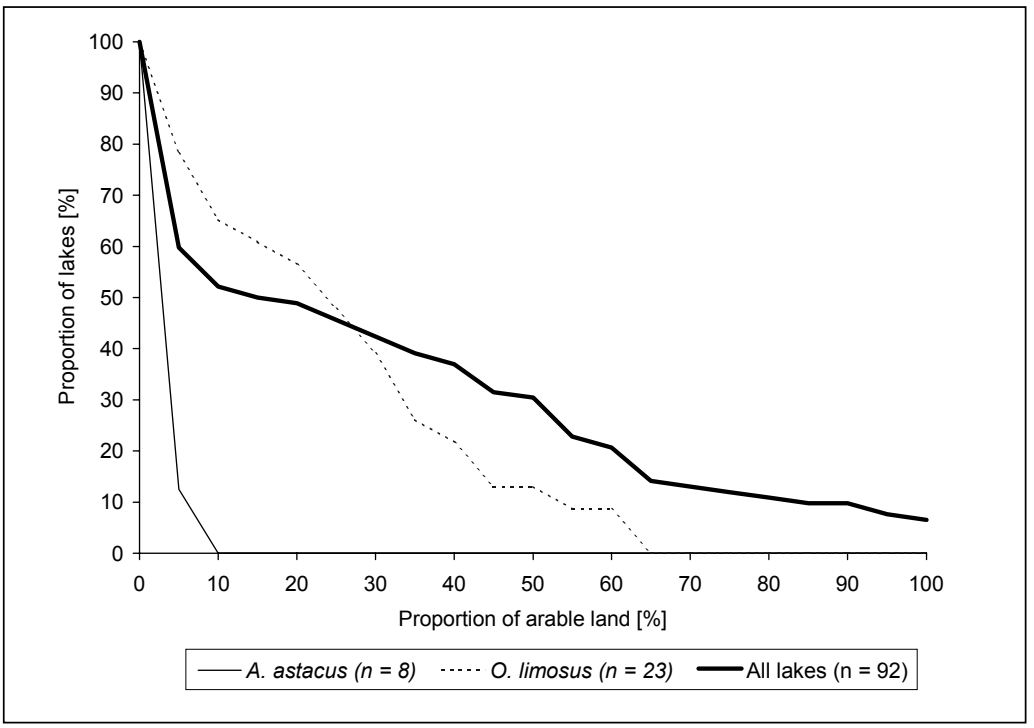

Figure 3

Dispersal of the examined lakes along a gradient of the proportion of arable land regarding the species $A$. astacus, $O$. limosus and all lakes. The presented proportion of lakes includes all lakes above a particular proportion of arable land.

Figure 3

Dispersion des lacs examinés le long d'un gradient de proportion de terres arables concernant les espèces $A$. astacus, $O$. limosus et tous les lacs. La proportion de lacs présentée inclut tous les lacs au-dessus d'une proportion particulière de terres arables. 


\section{DISCUSSION}

\section{Estimating land-use impact}

Only in the area of Bialy Bor does A. astacus represent the dominant crayfish species. In Prenzlau only one stock was found. In contrast, the introduced species O. limosus occurred in each of the three study areas. One parameter correlating with the observed distribution is the difference in land use. The present study reveals a relation between arable land and the distribution pattern of crayfish. $A$. astacus inhabited only lakes with less than $10 \%$ of arable land within the buffer. The area of Bialy Bor is characterised by a small proportion of arable land. The significance for the land-use feature « forest » is reciprocal. A. astacus was mostly found in lakes with a high proportion of forest. Bialy Bor features the highest proportion of forest compared with the other two study areas. $O$. limosus turned out to be more tolerant of arable land. This species occurred in lakes with a proportion of arable land up to $60 \%$. O. limosus was also indifferent to other types of land use.

Spatial analysis of landscape patterns has been employed for the assessment of aquatic habitat quality since the end of the 1980s (OSBORNE and WILEY, 1988; JOHNSTON et al., 1990; RICHARDS and HOST, 1994). Although the number of studies in the open literature is still small, it has been stated quite often that land-use properties have a strong impact on the aquatic community (SALLENAVE and DAY 1991; COOPER 1993). Analysis of habitat requirements of crayfish has concentrated so far on the water body and the shoreline of streams or lakes. NAURA and ROBINSON (1998), for example, used information on the habitat diversity of British rivers obtained by the River Habitat Survey (RHS) to predict the occurrence of native crayfish. Their analysis included 100 environmental variables, some of which were connected to land use. But land-use properties were not correlated with crayfish distribution. This could be traced back to the fact that all sites selected were of high water quality and thus feature little or no agriculture impact.

Undoubtedly, intensification of agriculture during recent decades has led to habitat destruction and increasing input of nutrients (HIGLER and REPKO, 1981), sediment (SCHULZ, 1996) and pesticides (SCHULZ, 1998) into aquatic ecosystems. The effects of agriculturally derived pollutants on aquatic organisms have been observed in several studies (HIGLER and REPKO, 1981; COOPER, 1993; SCHULZ and LIESS, 1999). Likewise it was stated for native crayfish that deterioration of water quality has had a strong negative impact on populations (WESTMAN, 1985). Although the extent of water pollution was not measured in the present study, GIS-based analysis strongly indicates the significance of agriculture in respect of crayfish distribution on a regional scale.

\section{Estimating other human impact}

As shown in this study, $O$. limosus preferentially occurred in larger lakes whereas A. astacus was found in smaller ones without direct contact to settled areas. Neither species showed a significant preference regarding the factor " distance to settlement area ». However, A. astacus stocks were most abundant in the area of Bialy Bor, where the average distance between lakes and settlements was highest. Also for Lower Saxony (BLANKE, 1998) and Bavaria (BOHL, 1987) most of the native crayfish stocks have been reported from remote areas.

The presence of alien crayfish is considered one of the main reasons for the endangered situation of native crayfish species such as $A$. astacus (SCHULZ and SMIETANA, 2001). American species are vectors of the crayfish plague and also compete with native species. When they have reached connected water bodies like rivers and canals, these alien species can spread by themselves and displace existing native crayfish 
populations. Therefore $O$. limosus forms continuous stocks in almost all large lowland rivers and their tributaries in Germany and Poland and is still expanding (HAGER, 1996; BOHL, 1999; DEHUS et al., 1999). In contrast, introduction of crayfish in lakes, which are more or less isolated habitats, is mostly due to human activities.

Transport of fishing gear or fishes for stocking is associated with a high risk of transferring living crayfish or crayfish plague (SPITZY, 1971; HAGER, 1996). Anglers, fishermen and other local people also distribute O. limosus to new lakes on purpose, following the common opinion that presence of crayfish indicates clean water, or in order to use crayfish as bait (TROSCHEL and DEHUS, 1993; STRUZYNSKI and SMIETANA, 1999). Extensive stocking with eel and other predatory fish is also among the human activities which threaten native crayfish stocks (BOHL, 1987). This study indicates that the parameters lake size and settlement area reflect the intensity of human activities. Generally, large lakes are more attractive for commercial fishermen and thus the probability of eradication of native crayfish populations and colonisation by alien crayfish species is high. This probability also increases for a small lake if it is situated near settlements or if it is easily accessible.

As with land use, the application of a geographic Information system is suitable for estimating overall human impact on crayfish distribution on a landscape level. This study demonstrates the utility of GIS for defining lakes suitable for crayfish habitation or for the analysis of potential risks for crayfish stocks. Thus GIS provides a powerful and effective tool for the conservation of native crayfish species. But a prerequisite for broad application would be a facilitated access to data on land use and species distribution.

\section{ACKNOWLEDGEMENTS}

We gratefully acknowledge the co-operation of Harald Wendt, Prenzlau, and the help of various persons with the field work. Data for GIS analysis were provided by the following organisations: Brandenburgisches Landesvermessungsamt, Landesumweltamt Brandenburg. The funding for the continuance of this project is provided by the Stiftung für Bildung und Behindertenförderung, Stuttgart and the NaturSchutzFonds Brandenburg. We also would like to thank the MUG Brandenburg e.V. for their support.

\section{REFERENCES}

ALBRECHT H., 1983. Besiedlungsgeschichte und ursprüngliche holozäne Verbreitung der europäischen Flußkrebse. Spixiana, 6, 61-77.

ALDERMANN D.J., 1996. Geographical spread of bacterial and fungal diseases of crustaceans. Revue scientifique et technique / Office International des Epizooties, $15,603-632$.

BLANKE D., 1998. Flusskrebse in Niedersachsen. Informationsdienst Naturschutz Niedersachsen, 18, 146-174.

BLASCHKE T., 1997. Landschaftsanalyse und -bewertung mit GIS. Methodische Untersuchungen zur Ökosystemforschung und Naturschutz am Beispiel der bayerischen Salzachauen. Forschungen zur deutschen Landeskunde, 243, Trier.

BLOHM H.P., GAUMERT D., KÄMMEREIT M., 1994. Leitfaden für die Wieder- und Neuansiedlung von Fischarten. Niedersächsisches Landesamt für Ökologie, Hildesheim, 76-79.

BOHL E., 1987. Comparative studies on crayfish brooks in Bavaria. Freshwater Crayfish, 7, 287-293. 
BOHL E., 1989. Ökologische Untersuchungen an ausgewählten Gewässern zur Entwicklung von Zielvorstellungen des Gewässerschutzes: Untersuchungen an Flußkrebsbeständen. Bayerische Landesanstalt für Wasserforschung, Wielenbach, $237 \mathrm{p}$.

BOHL E., 1999. Crayfish stock situation in Bavaria (Germany): Attributes, threats and chances. Freshwater Crayfish, 12, 765-777.

BOHL E., KELLER M., OIDTMANN B., 2001. Flusskrebse in Bayern. Information für Naturschutz, Wasserwirtschaft, Fischerei, Teichwirtschaft, Fisch- und Aquarienhandel, Gastronomie. Landesfischereiverband Bayern e.V., Bayerisches Landesamt für Wasserwirtschaft. $36 \mathrm{p}$.

COOPER C.M., 1993. Biological effects of agriculturally derived surface-water pollutants on aquatic systems - a review. Journal of Environmental Quality, 22, 402-408.

DEHUS P., 1990. Die Verbreitung der Flusskrebse (Decapoda ; Astacidae, Cambaridae) in Schleswig-Holstein. Faunistisch-ökologische Mitteilungen, 6, 95-105.

DEHUS P., 1996. Zur Pflege autochthoner Flusskrebs-Bestände. In: DEUTSCHE VETERINÄRMEDIZINISCHE GESELLSCHAFT E.V. / FACHGRUPPE FISCHKRANKHEITEN, Tagung der Fachgruppe Fischkrankheiten, 259-266.

DEHUS P., PHILLIPSON S., BOHL E., OIDTMANN B., KELLER M., LECHLEITER S., 1999. German conservation strategies for native crayfish species with regard to alien species. In : GHERARDI F., HOLDICH D.M. (Eds.), Crayfish in Europe as alien species. How to make the best of a bad situation?, Crustacean Issues, 11, 149-159.

FEDOTOV V.P.,RAKHMANOV V.R., KUZNETSOV N.L., 1993. The crayfish stocks and the state of crayfish breeding in the north-west of Russia. Freshwater Crayfish, 9, 170-173.

GARCIA-ARBERAS L., RALLO A., 2000. Survival of natural populations of Austropotamobius pallipes in rivers in Bizkaia, Basque country (North of Iberian Penninsula). Bull. Fr. Pêche Piscic., 356, 17-30.

GHERARDI F., HOLDICH D.M., 1999. Crayfish in Europe as alien species. How to make the best of a bad situation? Crustacean Issues, 11, $299 \mathrm{p}$.

HAGER J., 1996. Edelkrebse - Biologie, Zucht, Bewirtschaftung. Stocker, Graz, Stuttgart, $128 \mathrm{p}$.

HIGLER L.W.G., REPKO F.F., 1981. The effects of pollution in the drainage area of a Dutch lowland stream on fish and macroinvertebrates. Verhandlungen der Internationalen Vereinigung für Limnologie, 21, 1077-1082.

JOHNSTON C.A., DETENBECK N.E., NIEMI G.J., 1990. The cumulative effect of wetlands on streamwater quality and quantity. A landscape approach. Biogeochemistry, 10, 105-141.

KNUTH D., MIETZ O., 1993. Verbreitung, Gefährdung, Gewässeransprüche und Erhaltung des Edelkrebses Astacus astacus in Brandenburg. Naturschutz und Landschaftspflege in Brandenburg, 2/1993, 16-21.

MNLU, 1996. Fische in Thüringen. Ministerium für Landwirtschaft, Naturschutz und Umwelt, Erfurt, $118 \mathrm{p}$.

NAURA M., ROBINSON M., 1998. Principles of using River Habitat Survey to predict the distribution of aquatic species: an example applied to the native white-clawed crayfish Austropotamobius pallipes. Aquatic Conservation: Marine and Freshwater Ecosystems, 8, 515-527.

OSBORNE L.L., WILEY M.J., 1988. Empirical relationships between land-use/cover patterns and stream water quality in an agricultural watershed. Journal of Environmental Management, 26, 9-27.

RICHARDS C., HOST G., 1994. Examining land use influences on stream habitats and macroinvertebrates: a GIS approach. Water Resources Bulletin, 30, 729-738.

RICKLEFS R., 1979. Ecology. $2^{\text {nd }}$ ed, New York.

SALLENAVE R.M., DAY K.E., 1991. Secondary production of benthic stream invertebrates in agricultural watersheds with different land management practices. Chemosphere, 23, 57-76. 
SCHULZ R., 1996. A field study on the importance of turbidity and bed load transport of sediments for aquatic macroinvertebrates and fishes. Verhandlungen der Gesellschaft für Ökologie, 25, 247-252.

SCHULZ R., 1998. Macroinverebrate dynamics in a stream receiving insecticidecontaminated runoff. Proceedings of the International Association of Theoretical and Applied Limnology, 26, 1271-1276.

SCHULZ R., 2000. Status of the noble crayfish Astacus astacus (L.) in Germany: Monitoring protocol and the use of RAPD markers to assess the genetic structure of populations. Bull. Fr. Pêche Piscic., 356, 123-138.

SCHULZ R., LIESS M., 1999. A field study of the effects of agriculturally derived insecticide input on stream macroinvertebrate dynamics. Aquatic Toxicology, 46, 155-176.

SCHULZ R., SMIETANA P., 2001. Occurrence of native and introduced crayfish in northeastern Germany and northwestern Poland. Bull. Fr. Pêche Piscic., 361, 629-641.

SMITH G.R.T., LEARNER M.A., SLATER F.M., FOSTER J., 1996. Habitat features important or the conservation of the native crayfish Austropotamobius pallipes in Britain. Biological Conservation, 75, 239-246.

SPITZY R., 1971. Resistente, amerikanische Krebse ersetzen die europäischen, der Krebspest erliegenden Astaciden. Österreichs Fischerei, 24, 21-29.

STRUZYNSKI W., SMIETANA P., 1999. On the distribution of crayfish in Poland. Freshwater Crayfish, 12, 825-829.

TROSCHEL H.J., DEHUS P., 1993. Distribution of crayfish species in the Federal Republic of Germany, with special reference to Austropotamobius pallipes. Freshwater Crayfish, 9, 390-398.

WESTMAN K., 1985. Effects of habitat modification on freshwater crayfish. In : ALABASTER J.S. (ed.), Habitat modifications and freshwater fisheries, 245-255, Butterworths, London. 